\title{
COMPARISON OF ACTIVE SUMMER AND WINTER SPORTS TOURISTS IN A GERMAN HIGHLAND
}

\author{
Alexander Hodeck, Gregor Hovemann \\ Universität Leipzig, Leipzig, Germany
}

\begin{abstract}
ANNOTATION
The purpose of this research was to compare active summer and winter sports tourists in a highland destination regarding motivations within the destination choice process. Although climatic and demographic changes force these destinations to create all-year destination management strategies, there are no research projects dealing with this particular topic. Results of this research reduce that lack of knowledge and are helpful for developing marketing strategies in highland destinations.
\end{abstract}

Keywords: sports tourism, highlands, active sports tourists, destination choice process.

\section{INTRODUCTION}

The importance of sports tourism has risen during the last decades (Schwark, 2007). As the competition between providers of services within the field of sports tourism has also strengthened, not only theorists but also practitioners are interested in new findings in sports tourism. Understanding consumers is one major field within this topic (Konu, Laukkanen et al. 2011). Sport has become one of the major motives of German tourists (Aderhold, 2011). The destination choice process is of particular interest in sports tourism. Internal as well as external factors influence this process according to the model of P. Pearce (2005, p. 109), which is used in an adapted version by H. Konu et al. (2011, p. 1098) as the basis of this research. Motivators (internal factors) are used in this study to compare active summer and winter sports tourists. Literature review shows that there are a number of studies dealing with active summer or winter sports tourists and their motivation. White and Pennington-Gray (2002) interviewed winter sports tourists before and after their holidays. Motivation of the sports tourists did not change within this time. T. J. Dolnicar and M. Fluker (2003) surveyed 430 surfers for their motivation when choosing a particular surf destination. They stated that motivation of surfers differed relating to chosen destination. C. Meisel and S. Cottrell (2004) dealt with 300 scuba divers. This study showed that motivation of scuba divers related to their experience. T. J. Dickson and S. Dolnicar (2006) segmented 524 rock climbers by using factor analysis and network algorithm into six segments, which differed by their motivation. H. Woratschek et al. (2007) analysed climbers using a cluster analysis. In this study four segments differing regarding the motivation were identified. Z. Reynold and N. M. Hirtz (2012) questioned 347 surfers. These groups seemed to be very heterogeneous. Their motivation depended on age and experience. N. Boukas and V. Ziakas (2013) analysed 100 golf tourists in Cyprus. Four segments could be identified based on the motivation among these sports tourists. Although there are a number of studies dealing with motivation of active sports tourists, there is no study comparing active sports tourists of different seasons at all. Additionally, there is a lack of knowledge regarding sports tourism in highland destinations (peaks under 2.000 metres) in general. At the same time these destinations are especially forced to develop new strategies (Hodeck, 
Hovemann, 2013, p. 2) because of climate and demographic changes. Research subjects were active sports tourists in a traditional German highland destination (Erzgebirge or Ore Mountains) in summer and winter. In order to understand these sports tourists and their decisions better, analysing the destination choice process by using internal factors (motives) and the actual travel behaviour of sports tourists of different seasons are objectives of this investigation. As a consequence, differences or similarities of active sports tourists of different seasons can be described. The aim of this research was to reduce the research gap in sports tourism in general and sports tourism in highland destinations in detail. Additionally, findings are important for developing all-year marketing strategies in the investigated highland destination in future.

\section{RESEARCH METHODS}

Data were collected by using standardized questionnaires during the winter of 2013/14 and summer of 2014 in a German highland destination (Ore Mountains). This destination is situated in the south-east of Germany next to the Czech Republic. It is traditionally known as a winter sports destination. Data were only collected in the German part of the highland. Especially trained sports management students interviewed the subjects $(n=314)$ by using the area sampling method (Berekoven et al., 2001, p. 54). Data were collected in sports tourism places (places, where sports activities as skiing, biking or walking can be done). Number and distribution of these places in summer and winter are comparable. During both seasons, data were collected at four different times agreed before the research. Subjects were chosen by random selection on the site.

Table 1. Characterization of the sample

\begin{tabular}{|l|c|}
\hline \multicolumn{1}{|c|}{$\mathbf{N}$} & $\mathbf{3 1 4}$ \\
\hline Gender & Female: $52.1 \% ;$ Male: $47.9 \%$ \\
\hline Average age & 42.89 years \\
\hline Season & Summer: $45.1 \%$; Winter: $54.6 \%$ \\
\hline
\end{tabular}

Table 1 characterizes the sample, which is comparable to existing studies of this region (Hodeck, Hovemann, 2013). Active sports tourists of summer and winter were compared by sociodemographic variables firstly. Afterwards a factor analysis (PCA with varimax rotation) was used to reduce internal factors (motives) regarding the destination choice process. It was analysed whether summer and winter sports tourists consider the same factors as important or not. Finally, travel behaviours of summer and winter sports tourists were compared with each other. Differences were statistically analysed by the analysis of contingency for nominal data. Differences of quasi-metric data were proved by t-test or Welch-test (depending on the variances). These tests could be used as the data were distributed normally.

\section{RESEARCH RESULTS AND DISCUSSION}

First of all, active sports tourists of both destinations were compared by socio-demographic data. There was no significant correlation (Pearson's Chi-Square: 0.987, p > 0.5) between gender and chosen season. Summer sports tourists were almost 18 months older than winter sport tourists. 
However, there was no significant difference between active sports tourists in summer and winter regarding age, either.

Table 2. Differences between active winter sports tourists regarding gender

\begin{tabular}{|c|c|c|c|}
\hline \multirow{2}{*}{\multicolumn{2}{|c|}{ Tourists }} & \multicolumn{2}{|c|}{ Season } \\
\hline & & \multirow{2}{*}{$\begin{array}{l}\text { Summer } \\
89(89.1)\end{array}$} & \multirow{2}{*}{$\frac{\text { Winter }}{73(72.9)}$} \\
\hline & Female & & \\
\hline Oentue & Male & $82(81.9)$ & $67(67.1)$ \\
\hline
\end{tabular}

But there were significant differences between active sports tourists of the two seasons regarding the distances those people travelled to reach the destinations and the length of stay in the Ore Mountains. In winter, sports tourists travelled more than 200 kilometres longer to the chosen destination than in summer. At the same time these active sports tourists stayed almost two days longer within the destination. Looking at the actual travel behaviour, it is obvious, that active winter sport tourists in the Ore Mountains did not only spend more time within this region. They also spent significantly more money per day within the destination than those active sports tourists visiting the region in summer. Typical active winter sports tourists in the Ore Mountains spent $147.14 €$ per day within the destination while summer sports tourists spent only $88.58 €$ on average per day.

Table 3. Differences of active winter sports tourists regarding age, distance, and length of stay (averages)

\begin{tabular}{|l|c|c|c|c|}
\hline \multicolumn{1}{|c|}{ Aspect } & Summer & Winter & t-value & Significance \\
\hline Age (a) & 43.49 & 42.08 & 0.77 & Insignificant \\
\hline $\begin{array}{l}\text { Travelled distance } \\
\text { (km) }\end{array}$ & 65.08 & $\mathbf{2 8 6 . 3 1}$ & 6.16 & $\mathrm{p}<0.001$ \\
\hline Length of stay (d) & 2.84 & $\mathbf{4 . 9 6}$ & 5.87 & $\mathrm{p}<0.001$ \\
\hline
\end{tabular}

This difference even increased when calculating the expenditures of active sports tourists within a destination during a whole stay (expenditures per day multiplied with the length of stay). Sports tourists in winter spent almost three times more money during their whole stay in this destination $(729.81 €)$ than sports tourists in summer $(251.57 €)$ do.

Table 4. Differences of active winter sports tourists regarding expenditures per day (averages)

\begin{tabular}{|l|c|c|c|c|}
\hline \multicolumn{1}{|c|}{ Expenditures } & Summer & Winter & t-value & Significance \\
\hline Expenditures for drinks $(€)$ & 10.19 & 14.61 & 3.87 & $\mathrm{p}<0.001$ \\
\hline Expenditures for meals $(€)$ & 15.71 & 19.81 & 2.21 & $\mathrm{p}<0.05$ \\
\hline Expenditures for sleeping (€) & 44.15 & 62.50 & 2.18 & $\mathrm{p}<0.05$ \\
\hline Expenditures for sporting activities $(€)$ & 11.50 & 36.77 & 5.10 & $\mathrm{p}<0.001$ \\
\hline Expenditures for others $(€)$ & 7.03 & 13.45 & 1.83 & Insignificant \\
\hline
\end{tabular}

Motivation influencing the destination choice process seemed to be usable for a factor analysis (KMO-Criteria: 0.666). A Chi-Square value of 584.17 ( $\mathrm{p}<0.001$ ) confirmed this, too. Six factors explaining $72.3 \%$ of the variance were extracted. These factors can be described as "Feel comfortable", "Take a break", "Be active healthily", "Experience being together", "Just relax" and "Experience nature". The motivation used for this analysis was taken from the "Deutsche Reiseanalyse" (Aderhold, 2011), in which it has been used since more than 30 years and adapted 
regularly. Within a pre study, out of the existing 30 motivators of the "Reiseanalyse", which were most important to tourists of this destination, 15 were extracted and used for the factor analysis.

Finally, it was analysed whether there were differences between active sports tourists in summer and winter regarding the importance of these factors within the destination choice process or not. Obviously, persons choosing the Ore Mountains in summer and winter did not differ regarding the importance of most motivational factors. Significant differences only were observed for two factors. These were "Feel comfortable" and "Just relax".

Table 5. Results of the factor analysis

\begin{tabular}{|c|c|c|c|c|c|c|}
\hline Motivation factors & 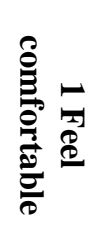 & 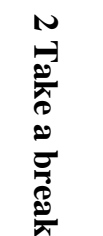 & 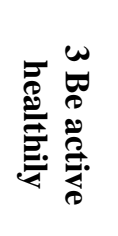 & 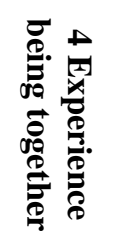 & 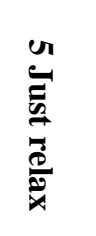 & 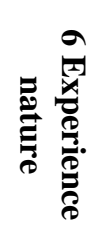 \\
\hline Get new impressions & 0.745 & & & & & \\
\hline Be indulged & 0.720 & & & & & \\
\hline Healthy climate & 0.713 & & & & & \\
\hline Have time for each other & & 0.731 & & & & \\
\hline Away from it all & & 0.666 & & & & \\
\hline Refuel & & 0.566 & & & & \\
\hline Relax, no stress & & 0.527 & & & & \\
\hline Do sport actively & & & 0.744 & & & \\
\hline Soft sport / fitness & & & 0.691 & & & \\
\hline Do something for your health & & & 0.626 & & & \\
\hline Experience something with friends & & & & 0.729 & & \\
\hline Fun, pleasure & & & & 0.712 & & \\
\hline Rest, laze & & & & & 0.797 & \\
\hline Be free, have time & & & & & 0.714 & \\
\hline Experience nature, landscape & & & & & 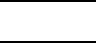 & 0.913 \\
\hline
\end{tabular}

Active summer sports tourists placed more importance to "Feel comfortable" and "Just relax" than active winter sports tourists. There were no significant differences between the tourists in other four factors. The most important factors to all sport tourists were "Take a break" and "Experience nature". Although all people who were interviewed answered that doing a kind of sport was the main reason for their visit, "Being active healthily" was less important than other factors.

Table 6. Differences between active summer and winter sports tourists regarding average importance of motivational factors ( 1 - not important at all, 5 - very important)

\begin{tabular}{|l|c|c|c|c|}
\hline \multicolumn{1}{|c|}{ Motivation factors } & Summer & Winter & t-value & Significance \\
\hline Feel comfortable & 3.90 & 3.52 & 4.13 & $\mathrm{p}<0.001$ \\
\hline Take a break & 4.32 & 4.33 & 0.05 & Insignificant \\
\hline Be active healthily & 3.43 & 3.59 & 1.82 & Insignificant \\
\hline Experience being together & 4.08 & 4.09 & 0.16 & Insignificant \\
\hline Just relax & 4.03 & 3.80 & 2.42 & $\mathrm{p}<0.05$ \\
\hline Experience nature & 4.24 & 4.45 & 0.76 & Insignificant \\
\hline
\end{tabular}

Comparing this study with existing studies (e.g. Hodeck, Hovemann, 2013) it is surprising that there are more female than male active sports tourists. Maybe, new marketing strategies helped to increase the number of female sports tourists already. Active summer and winter sports tourists 
within the analysed destination did not differ regarding gender, age and most of the motivational factors. So it can be stated that a destination may attract comparable target groups throughout different seasons. Looking at other studies (e.g. Hodeck, Hovemann, 2014) we suggest that there are significant differences between active sports tourists within several destinations.

\section{CONCLUSIONS AND PERSPECTIVES}

As a conclusion, it seems to be more helpful to develop destination specific marketing strategies across the whole year than trying to develop marketing strategies for comparable types of destinations (e.g. highland destinations) because there are only a few significant differences between sports tourists in summer and winter regarding the destination choice process. This conclusion contributes directly to reducing the lack of knowledge in the field of sports tourism. Sports tourists of the investigated seasons are also comparable according to gender and age, too. However, regarding the Ore Mountains there are significant differences between active summer and winter sports tourists regarding the length of stay, travelled distance to the destination and expenditure within the destination. As a consequence, one major task for marketing managers of the Ore Mountains is to develop offers and marketing strategies in order to attract active summer sports tourists as much as tourists in winter. As there are comparable target groups, this task seems to be realisable. Creating a number of attractive offers for being active is the main task to reach that goal. These offers should be of high quality and service orientated, as they can be found in the winter season. At the same time these offers should allow experiencing the nature of the destination, as this factor is most important to active sports tourists.

In order to prove the results of this cross-sectional analysis further research should be carried out comparing active sports tourists of summer and winter with sports tourists in the Czech part of the highland, in other destinations or during a longer period of time. Developing marketing strategies usable for the whole year is important in general. Highland destinations are especially forced to be active in that field because they are affected by climate changes even more than other destinations (high mountains). As a consequence, developing attractive summer sports activities is very important for highland destinations in general. In order to achieve this, analysing several types of active sports tourists as bikers, hikers or runners in detail should be in the focus of future studies, too.

\section{REFERENCES}

1. Aderhold, P. (2011). Die Urlaubsreisen der Deutschen. Kurzfassung der Reiseanalyse 2011. Kiel: FUR.

2. Berekoven, L., Eckert, W., Ellenrieder, P. (2001). Marktforschung. Methodische Grundlagen und praktische Anwendungen (9). Wiesbaden: Gabler.

3. Boukas, N., Ziakas, V. (2013, June). Golf Tourist Motivation and Sustainable Development: A Marketing Management Approach for Promoting Responsible Golf Tourism in Cyprus. Presented at the 3rd International Conference on Tourism (ICOT 2013), Limassol, Cyprus. (Downloaded on November, $7^{\text {th }}$

from 
http://www.academia.edu/3568662/Golf_Tourist_Motivation_and_Sustainable_Development_A_Market ing_Management_Approach_for_Promoting_Responsible_Golf_Tourism_in_Cyprus.

4. Dickson, T. J., Dolnicar, S. (2006). Ascending Mount Kosciusko: An exploration of motivational patterns. Research Online. (Downloaded on November, $7^{\text {th }} 2014$ from http://ro.uow.edu.au/cgi/viewcontent.cgi?article=1067\&context=commpapers.

5. Dolnicar, S., Fluker, M. (2003). Behavioral market segments among surf tourists - investigating past destination choice. Journal of Sport Tourism, 8 (3), 186-196.

6. Hodeck, A., Hovemann, G. (2013). Typisierung von Wintersporttouristen in deutschen Mittelgebirgen am Beispiel des Erzgebirges. Sciamus, 4 (4), 1-13.

7. Hodeck, A., Hovemann, G. (2014). Empirical findings for destination-specific marketing strategies in German winter sport tourism. Polish Journal of Sport \& Tourism (in press).

8. Konu, H., Laukkanen, T., Komppula, R. (2011). Using ski destination choice criteria to segment Finnish ski resort customers. Tourism Management, 32, 1096-1105.

9. Meisel, C., Cottrell, S. (2004). Differences in motivation and expectations of divers in the Florida keys. In J. Murdy (Ed.), Proceedings of the 2003 Northeastern Research Symposium (pp. 393-401).

10. Pearce, P. (2005). Tourist Behaviour: Themes and Conceptual Schemes. Clevedon: Channel View.

11. Reynolds, Z., Hritz, N. M. (2012). Surfing as adventure travel: Motivations and lifestyles. Journal of Tourism Insights, 3 (1), 14-23.

12. Schwark, J. (2007). Sport tourism: Introduction and overview. European Journal of Sport and Society, 4 (2), 117-132.

13. Woratschek, H. Hannich, F. M., Ritchie, B. (2007). Motivations of Sport Tourists - An Empirical Analysis of Several European Rock Climbing Regions. Downloaded on June, 24th 2014 from http://www.fiwi.uni-bayreuth.de/de/download/WP_02-07.pdf

\title{
COMPARISON OF ACTIVE SUMMER AND WINTER SPORTS TOURISTS IN A GERMAN HIGHLAND
}

\author{
Alexander Hodeck, Gregor Hovemann \\ Universität Leipzig, Leipzig, Germany
}

\begin{abstract}
Research background. During the last decades the importance of sports tourism has risen (e.g. Schwark, 2007). A lot of new destinations have developed and existing destinations have expanded. Gaining information about sports tourists is important for destinations because of the increased competition in that field. On the other hand, the phenomenon of sports tourism has also become the focus of scientific work. Understanding consumers is one major field within this topic (Konu, Laukkanen, Kommpula, 2011). The destination choice process is of particular interest. According to the model of P. Pearce (2005, p. 109) adapted by H. Konu et al. (2011, p. 1098), which is used in this research, internal as well as external factors
\end{abstract}


influence the destination choice process in sports tourism. Sports tourism plays an important role in German highland destinations (Aderhold, 2011). Traditionally, these destinations concentrate on winter sports tourism. As a consequence of climate and demographic changes, creating all-year marketing strategies is important. At the same time, there is a lack of knowledge regarding studies dealing with the comparison of sports tourists of different seasons.

Research aim. This study deals with internal factors influencing destination choice and tourism behaviour of active sports tourists. The main objective of this research was to investigate whether there were differences between active sports tourists in summer and winter or not. Therefore, active summer and winter sports tourists of one German highland destination (Ore Mountains) were compared.

Methods. Data were collected using a standardized questionnaire during one winter and one summer season. Differences between active summer and winter sports tourists regarding socio-demographic variables were examined firstly. Afterwards a factor analysis (PCA with varimax rotation) was used to reduce internal factors (motives) in order to investigate whether there were differences regarding the destination choice process. Finally, travel behaviour of active sports tourists was analysed. Significance of differences was statistically proved by analysis of contingency, t-test or Welch-test.

Results and conclusions. Active summer and winter sports tourists of the Ore Mountains do not differ regarding age and gender. Out of 15 motives influencing the destination choice process six factors could be extracted. Summer and winter sports tourists differ only in two of them from each other. There are differences regarding the length of stay, travelled distance to destination and expenditure within the destination. Active sports tourists in winter stay longer, travel a longer distance to reach the Ore Mountains and spend more money there. As a conclusion, developing all-year marketing strategies for active sports tourists of one destination seems to be helpful, as tourists of different seasons are comparable. Of course, this study can provide only initial information about the comparison of active sports tourists of different seasons. In order to generalize the findings, further research should be done.

Keywords: sports tourism, highlands, active sports tourists, destination choice process. 